\title{
Making Cities Resilient in Ghana: The Realities of Slum Dwellers That Confront the Accra Metropolitan Assembly
}

\author{
Ronald Adamtey ${ }^{1}$, John Victor Mensah ${ }^{2} \&$ Gifty Obeng ${ }^{3}$ \\ ${ }^{1}$ Department of Planning, Kwame Nkrumah University of Science and Technology, Kumasi, Ghana \\ ${ }^{2}$ School for Development Studies, University of Cape Coast, Cape Coast, Ghana \\ ${ }^{3}$ Good Governance Africa, Accra, Ghana \\ Correspondence: Ronald Adamtey, Department of Planning, Kwame Nkrumah University of Science and \\ Technology, Kumasi, Ghana. E-mail: radamteysekade@gmail.com
}

Received: December 28, 2020

doi:10.5539/jsd.v14n1p70

\author{
Accepted: January 19, $2021 \quad$ Online Published: January 28, 2021 \\ URL: https://doi.org/10.5539/jsd.v14n1p70
}

\begin{abstract}
Over the past three decades, various countries and stakeholders have aimed at having cities that can better handle natural and human-made disasters, protect human life, absorb the impact of economic, environmental and social hazards and promote well-being, inclusive and sustainable growth. This paper investigates how informal ties result in in-filling and the creation of slums in the context of efforts to make cities resilient in Ghana using the Accra Metropolis as case study. The United Nations Habitat classification of slums was used to purposively select two slum settlements in Accra for the study. The study used mixed methods of quantitative and qualitative approaches to collect data from April 2018 to August 2018. Quantitative data was collected from 400 slum dwellers while qualitative data was collected from eight focus group discussion sessions and in-depth interviews with at least one senior official from related institutions such as Accra Metropolitan Assembly (AMA), Ministry of Local Government and Rural Development (MLGRD), Ministry of Water Resources (MWR), Ministry of Works and Housing (MWH), Ministry of Inner City and Zongo Development (MICZD), Environmental Protection Agency (EPA), Ghana Police Service, and Ghana National Fire Service. Descriptive techniques were used for the analysis. The findings are that informal ties contribute to in-filling in slums. Slum dwellers do not plan to return home, they are not involved in land use decision making and the slums have opportunities and challenges to the slum dwellers and AMA. The AMA should avoid forced eviction of slums and rather enforce development control bye-laws, implement slum upgrading programs, and involve slum dwellers in upgrading programs. Slum dwellers must cooperate with AMA to make Accra resilient. The mainstreaming of the issue of slums in all urban development agendas needs to be given the needed political and policy attention by central government and all stakeholders.
\end{abstract}

Keywords: slums, decentralization, resilient cities, metropolitan assembly, Ghana

\section{Introduction}

The concern to make cities in Africa including Ghana resilient has received increased scholarly and policy interest over the past three decades. The rationale is that in the event of internal and external shocks, cities must have the ability to adapt, respond and deliver essential urban services to residents. Resilient city is therefore the ability of an urban system and all its constituent socio-ecological and socio-technical networks to maintain or rapidly return to desired functions in the face of a disturbance. Thus, a resilient city has developed capacities to absorb future shocks and stresses to its economic, social, environmental, security and technical systems as well as infrastructure to maintain essentially the same functions, structures, systems, and identity (Wagner \& Breil, 2013; Albino et al., 2015; Neirotti et al., 2014). Such a city should be liveable, capable, secured and competitive.

This concept of resilient cities is considered a solution to emerging challenges facing cities in the $21^{\text {st }}$ Century and beyond. With this thinking, cities need to use the available internal potentials to promote innovation, efficiency and sustainability in all the dimensions of development including governance, economy, social, environment and security (Komninors et al., 2013). Global support for resilient cities is evident in all the United Nations 17 Sustainable Development Goals. Goal 11 specifically seeks to make cities and human settlements inclusive, safe, resilient and sustainable (UN, 2016). Achieving resilient cities comes with advantages in the city's economic, social, environmental, security and other spheres (International Council for Local Environmental Initiatives, ICLEI, 
2017). There is the argument that resilient cities would aid cities assessing their strengths, vulnerabilities, and exposure to natural and man-made threats in order to build adaptive and preventive mechanisms required for sustainable development.

Resilient cities have existing and environmentally friendly mechanisms, including risk-based instruments to reduce exposure and vulnerability to shocks and increase cities' adaptive capacity; and support capacity development needed to maintain their functionality. Environmentally, resilient cities integrate urban flood and coastal zone management with advanced disaster preparedness, responses and craft a climate risk management approach (see Cities Alliance, 2014; 2019; UN, 2016; UN-Habitat, 2010). Economically, resilient cities strengthen rural-urban linkages which can foster livelihoods and increase employment in both rural and urban communities. Socially, resilient cities have less social inequalities and a fairer distribution of resilient resources. In terms of governance, a resilient city has an inclusive decision-making processes in the realm of planning, open dialogue, accountability, and collaboration (Jabareen, 2013).

Evidence shows that one of the important issues that have undermined efforts aimed at achieving resilient cities is the creation of slums (Parmer et al., 2016; United Nations Human Settlements Programme, 2003; Cities Alliance, 2019). Slums emerge in many cities in developing countries mainly due to increased urbanization and weak provision of social amenities like housing, water, sanitation and healthcare (Cohen, 2006; Gowda et al., 2013).

Slums have been described as illegal settlements or part of urban areas characterized by overcrowding, poor quality housing, inadequate access to potable water, poor sanitation and inadequate socio-economic infrastructure such as schools, hospitals, public places and access roads. They have high rate of crime, unemployment, and drug addiction (Weinstein, 2014; UN-Habitat, 2011; 2013, 2015).

Out of the more than half of the world's population living in cities, approximately a quarter live in slums (United Nations, 2016) and this is projected to double by 2030 if nothing is done about the current trend (UN-Habitat, 2010; Elrayies, 2016). In Africa, more than half of the population in cities (61.7\%) live in slums (UN-Habitat, 2013). There is some consensus that achieving resilient cities brings huge responsibilities to local governments. Therefore, decentralized local governments such as the Accra Metropolitan Assembly in Ghana are key implementers of resilient city policies yet the realities that confront them do not appear to have received adequate scholarly attention.

Existing studies have shown that rural-urban migration, socio-economic factors and environmental factors are among the major causes of slums (Cities Alliance, 2014; 2019; Gowda et al., 2013). Some have suggested that regulatory and legal measures should be taken to address slums (Gowda et al., 2013). Others such as Cities Alliance (2019) argue that urbanization is a reality that governments must recognize and work to make cities resilient and in addition to policies focusing on rural development to minimize rural-urban migration, policies geared towards making cities resilient must be given increased attention.

The problem however is that current literature on the causal factors of slums and the prescribed policy options do not provide adequate understanding of the realities of slums and ways to approach them. What is not adequately explored is whether slum dwellers who are mostly migrants from rural areas have plans to return to their places of origin. In what ways do new migrants into the slums find accommodation leading to the infilling in the slums? What opportunities are there in the slums that make such places attractive, and what challenges confront the slum dwellers and the city authorities at the AMA? Hence the specific objectives of this paper are to: (a) analyze the informal ties that cause in-filling of slums; (b) investigate whether or not slum dwellers have plans to return to their places of origin; (c) examine the opportunities in the slum communities; (d) examine the challenges facing slum dwellers and city authorities; and (e) suggest how the city of Accra can be made resilient.

Our argument in this paper is that socio-cultural issues of informal ties, plans of slum dwellers to remain in the cities permanently and the opportunities of slums to slum dwellers need to be recognized, understood and incorporated into plans by city authorities in order to achieve resilient cities as envisaged by Ghana's Land Use and Spatial Planning Act, 2016 (Act 925) (Republic of Ghana, 2016a).

The paper is structured in six sections. After the introduction, the next section reviews relevant literature. The third and fourth sections deal with the study context and methodology for the study respectively. The fifth section presents the findings and discussion. The sixth section is on the conclusions and recommendations.

\section{Literature Review}

Review of literature focuses on the theory of informal ties, theory of slum of hope and slum of despair, decentralization and resilient cities, the global trend in dealing with slums and how Ghana has dealt with slums so far. 


\subsection{The theory of Informal Ties}

Relationships between people at a personal level have been described by Coleman (1991) as informal ties. They deal with how informal circle of people are able and willing to help each other (Grodeland, 2005). They may involve a complex combination of "weak ties (relationship with acquaintances and friends of friends) and strong ties (relationship with friends, relatives, and neighbours)" (Granovetter, 1983: 207). Informal ties may generally include ethnic ties, friendship ties, old-school networks, neighbourhood ties, political party affiliations, and religious affiliations. For many countries in Africa, informal ties remain very important as noted by Kimenyi and Mbaku (2004: 113) that "while many changes have taken place in Africa over the last 40 years ... little has changed in regard to the attachment and loyalty that individuals have towards members of their ethnic group." As members of an informal network share benefits that accrue to that network, they hold an obligation to it; any failure to promote the interest of the members could result in exclusion from the group (Woolcock \& Narayan, 2000; Widner $\&$ Mundt, 1998). Social relations are self-sustaining when intrinsic incentives accrue to both parties. The incentives are generated by the relation itself and continuation of the relation depends on it generating sufficient incentives for both parties (Coleman, 1991).

Essential ties to many in Africa include ethnic, family, kinship and neighborhood networks. Family ties mostly extend beyond the nuclear family to include the extended family and neighbors as well. A neighbor in this study is taken to mean colleagues at work and the people with whom we live in the same neighborhood in the city. These are people who also live and work away from their kinsmen and families. In Ghana, it can be difficult to locate the boundary of the family with the emergence of the new family or the 'abusua'. The 'abusua' in Ghana is an Akan word for family. Most people who reside and work in urban areas find themselves to be away from their immediate families. As a result, they take the friends they make in the cities and colleagues at work as their abusua (the new family). This is because the abusua plays most of the role of actual families in terms of offering various kinds of support (Hanson, 2004). They also come with obligations that enjoin members of the abusua who have access to opportunities to extend them to other members (Alesina \& Giuliano, 2007; Clark, 1999). Literature shows that social networks and ties help many rural dwellers to migrate into the city by providing information about jobs, accommodation and ways of migration (BRAC, 2016). These ties also help them to settle in quickly. Besides the support that one would receive from key social institutions such as marriage, child naming ceremonies, and bereavement, one's social ties provide channels to access a wide range of resources and opportunities (Clark, 1999).

Many people may invoke these ties to obtain the approval from members in their networks to do extensions to existing structures in the cities leading to the in-filling and congestion. As such ties can help shape the behaviour of public officials (Hoxha et al., 2014), these realities might affect plans to achieve resilient cities by local governments most especially when many slum dwellers are enticed with the promise of urban opportunities. Although many end up being disappointed as we find in Stokes (1962)'s theory of slums of hope and despair.

\subsection{The Theory of Slums of Hope and Slums of Despair}

According to Stokes (1962: 189), slums can be classified into slums of "hope" and slums of "despair". By "hope", it is those slum residents who are psychologically convinced that they can improve upon their living conditions and put in the effort to work towards this with some ideas of the possible outcomes of their efforts. These slum dwellers are employable and might find jobs in the urban environment due to their age or educational ability.

The second is "despair", those slum residents who lack the psychological conviction that they can improve their conditions and do not foresee any positive outcomes from their efforts to change their conditions. This group of slum dwellers are unemployable by existing urban jobs.

The slums of "hope" are the home to the in-migrants who move into the city with the hope of improving their lives. But if they do not possess the requisite language and necessary educational qualifications together with other socioeconomic resources, they might not be able to change their living conditions although that possibility might exist.

Under normal conditions, many of the strangers residing in the slums of hope will eventually be absorbed into the city's employable population. This becomes possible because they will learn the language, get socialized, integrated and will gradually accumulate the needed socio-cultural resources needed.

For reasons such as their inability to meet the ability requirements of the city, some of the immigrants in the slums of "hope" cannot be able to change their living conditions and move up the socio-economic ladder. Thus, some will end up in slums of "despair," Therefore, it is in the slums of "despair" that the poor live. These will be those whose standards of living fall below acceptable levels specified by the government as expenditures for basic subsistence. The role of local governments in responding to slums is critical to making cities resilient. 


\subsection{Decentralization and Resilient Cities}

In the view of Crawford (2010: 94), "decentralization entails the transfer of power, responsibilities and finance from central government to sub-national levels of government." In the Ghanaian context, decentralization is the process of transferring power and resources from central government to the regions, municipalities and districts (CDD, 2005). Oyugi's (2000, 2008a, 2008b) view is that decentralization involves sharing and ceding of power and authority to lower-level units to act on behalf of the centre. All these definitions point to some agreement that decentralization is the transfer of power, authority, and responsibility by the central government to local government bodies for them to deliver services to citizens (Rondinelli, 1990a, 1990b; Cheema \& Rondinelli, 2007; DFID, 2008; Devas, 2008).

The claim is that decentralization can lead to responsive governance outcomes. Local government is said to have the potential to deliver services in line with the demands of local people as development can be effectively tailored to suit local needs (Crook, 2003; World Bank, 2004; Ayee, 2008). The argument that decentralization can lead to responsiveness is based on two assumptions. First, local politicians are close to the people so they are in a better position to use local knowledge to deliver appropriate needs. Ultimately, the process can lead to efficiency in service delivery (Smith, 1985; Agyeman-Duah, 2005). Second, decentralization can enable citizens at the local level to hold public officers accountable for their actions as they can vote out councillors that they find to be corrupt or inefficient (Blair, 2000; Wanyande, 2004; Wekwete, 2007).

Ghana adopted decentralization reforms about three decades ago with the promulgation of PNDCL 207 (1988). Ghana's 1992 Constitution affirms the choice to transfer decision making powers to sub-national governments to steer the development agenda at the local level (Republic of Ghana, 1992). The reforms are supported by the Local Government Act, 1993, Act 462 and the Local Governance Act, 2016 (Act 936) (Republic of Ghana, 1993; 2016b). The implementation of the reforms led to the establishment of District Assembly system as the highest political authority at the local level. District Assemblies have the responsibility to spearhead local initiatives and mobilize local resources for development at the sub-national level (Republic of Ghana, 1992; 1993; 2016b). As provided for in Section 12 (sub-section 1 to 5) of Act 936, District Assemblies are expected to provide basic infrastructure and services in education, health, water and other programs to improve the quality of life of people in their localities.

To make cities resilient, Section 12 sub-section 3(f) states that District Assemblies shall be responsible for the development, improvement and management of human settlements and the environment in the district (Republic of Ghana, 2016b). National policies such as the National Spatial Development Policy Framework (2015-2035), National Housing Policy (2015), and National Urban Policy Framework and Action Plan (2012) all provide the framework and basis for urban renewal or slum upgrading, slum decongestion and forced eviction when necessary. All these provisions have informed efforts with which Ghana has dealt with slums which, to a large extent, is informed by the global trend. For a good understanding of Ghana's experience, a brief presentation of global approach to dealing with slums might be useful.

\subsection{Global Trend in Dealing with Slums}

The global trend in dealing with slums has been described by Gill-Chin (1987) as traditional housing policies where many governments have used regulatory measures by controlling land and housing prices. The basis of this is that since it is expensive for the poor to acquire land and housing, the freezing of prices will enable the poor to afford decent housing. Governments have also used regulations to set minimum standards to prevent the building of poor and unsafe housing. Additionally, many governments have employed forced eviction of slums to discourage further expansion. The use of green belt around the city to prevent invasion and encroachment is yet another measure. Others have used policies to redistribute population so that there will not be population concentration in the cities leading to increased demand on housing. Evidence suggests that these policies have not worked well and rather produced harmful effects on the housing condition of the poor. Based on the failures of traditional housing policies, efforts have now shifted to policies such as site and services to meet the housing need of the poor (Gill-Chin, 1987).

\subsection{How Ghana Has Dealt with Slums So Far}

Ghana's approach to dealing with slums includes urban renewal with slum upgrading and forced eviction.

From 1996 to 2000, under a World Bank funded urban environmental sanitation project, Ghana's major cities of Accra, Kumasi, Takoradi, Tamale and Tema faced with the issue of slums, were targeted for urban development. The project sought to enhance productivity and improve the living standards targeting those classified as lower income, improvement in solid waste management, sanitation and drainage.

In collaboration with the African Development Fund, Ghana implemented the urban poverty reduction strategy in 
2005 targeting urban centers with inadequate infrastructure and services (Africa Development Fund, 2005; Amoako \& Cobinnah, 2011). Under UN-HABITAT slums upgrading facility, Ghana implemented slum and urban upgrading aimed at the development of new low- income housing and associated infrastructure in 2008. Some of the slum communities that benefitted include Aboabo and Asawase in the Kumasi Metropolis and Ashaiman and Ga Mashie in the Greater Accra region (UN Habitat, 2020).

For urban renewal, the government of Ghana has implemented a number of initiatives. As provided by Act of Parliament, 2017 (Act 964), the Inner City and Zongo Development initiative was implemented to improve the living conditions of the urban poor (Republic of Ghana, 2017). Among the objectives are the investment in basic social services and strategic infrastructure in zongo communities and the provision of social protection for the vulnerable in such communities.

Decongestion, forced eviction and demolition of slums have also been common in Ghana with the thinking that slum dwellers will return permanently to their places of origin (Broadnet, 2012; Akuffo, 2014; Aba \& Owusu, 2018; Adolga-Bessa, 2019). As noted by Gilbert (2007), slum demolishing is most preferred by governments in developing countries including Ghana in spite of the several wars waged by Human Rights Advocates and Civil Society organizations. Local governments such as the Accra Metropolitan Assembly (AMA) and the Kumasi Metropolitan Assembly have pursued this approach for many years (Obeng-Odoom \& Amedzro, 2011). For example, in April 2020, the AMA embarked on a demolition exercise at Old Fadama in Accra to pave way for the dredging of the Korle Lagoon. The result was that over 1,000 slum-dwellers were rendered homeless. This action was criticized by Human Rights groups on the basis that the affected persons are at high risk of contracting the coronavirus as no alternative measures were put in place to mitigate the impact of the demolishing and protection from COVID-19 (Ghanaweb, 2020). Generally, forced evictions and demolishing of illegal housing structures in the slums have not achieved the desired purposes (Ekott, 2018; Elrayies, 2016; Psirmoi, 2018). Many of these initiatives did not yield the needed results mainly due to challenges such as the lack of education, coordination and collaboration with city management institutions and the lack of involvement of the beneficiaries (Amoako \& Cobbinah, 2011).

\section{The Study Context}

According to the UN-Habitat's (2011) classification of slums in Ghana, there are 21 slums in Accra and the popular ones are Agbogbloshie and Avenor. We therefore, purposively selected Agbogbloshie and Avenor. These two communities easily get flooded with reported cases of deaths (Myjoyonline, 2019).

The Agbogbloshie community is situated on the banks of the Korle Lagoon, adjacent to Old Fadama in the NorthWest of Accra's Central Business District (Afenah, 2010; Environmental Justice Organization, 2017). Agbogbloshie is classified as one of the most polluted slums in the world by hosting one of the largest households and electronic waste dumps and informal sector recycling in Africa. It produces 250,000 metric tons of waste annually of which about $80 \%$ is E-waste (Environmental Justice Organization, 2017; AMA, 2018; Oteng-Ababio, 2019).

Residential dwelling is a mixture of concrete structures and wooden shacks inhabited by mostly unrelated families who have formed new types of social bonds and networks with support systems as described by informal ties theory (Coleman, 1991; Clark, 1999, Hanson, 2004). As one of the major vegetable markets and a scrap yard, its residents come from every part of Ghana and other countries in the West African sub-region mainly to look for jobs (Cassels \& Jennes, 2014; Adamtey et al., 2019). It is densely populated with all the characteristics of slums (Cassels \& Jennes, 2014; Ghana Statistical Service, 2012).

The Avenor community is located in the Okaikoi South Sub-Metropolitan Area of the Accra Metropolis. It is bounded to the North by Alajo and Tesano, to the West by North Industrial Area, to the South by Adabraka and South Industrial Area, and to the East by Kokomlemle and Kpehe. Avenor's population constituted about 7\% of the entire population of the Okaikoi South Sub-Metropolitan Area with a population of about 8,577 people in 2010 (Ghana Statistical Service, 2012; AMA, 2019). It is one of the slums in Accra characterized by poor road networks, poor drainage systems and insufficient water and electricity services. The housing landscape of the community consists of indigenous, low class and high-density development with depressed condition (CHF International, 2009).

\section{Study Methodology}

The study philosophy is based on pragmatism. Both quantitative and qualitative data were collected in the slums from April 2018 to August 2018. Quantitative data was in the form of place of birth, migration history, the age and sex of respondents and number of the various categories of respondents who held views about plans to return 
permanently and the types of networks they belonged to. Since age and sex can affect people's social ties and networks, in both communities, we used the cluster method to group the respondents into male youth, female youth, male adults and female adults (Johnson \& Reynolds, 2005). The objective was not to obtain a representative sample but rather to obtain a good number of the respondents to be used to map the networks and social ties. Consequently, within each cluster for each community, systematic random method was used to sample every fifth person in the cluster until 50 persons were obtained (see Table 1). In all, 200 youth aged between 18 and 35 years (100 males and 100 females), 200 adults (100 adult males and 100 adult females who were above 35 years) were selected for interviews in the two communities using 10 field assistants.

Table 1. Slum dweller interviewees and focus group discussion participants in Agbogbloshie and Avenor by cluster

\begin{tabular}{ccccccc}
\hline \multirow{2}{*}{ Cluster } & \multicolumn{3}{c}{ Interviewees } & \multicolumn{3}{c}{ FGD Participants } \\
\cline { 2 - 7 } & Agbogbloshie & Avenor & Total & Agbogbloshie & Avenor & Total \\
\hline Youth (Females) & 50 & 50 & 100 & 15 & 16 & 31 \\
Youth (Males) & 50 & 50 & 100 & 17 & 12 & 29 \\
Adult (Females) & 50 & 50 & 100 & 14 & 11 & 25 \\
Adult (Males) & 50 & 50 & 100 & 13 & 10 & 23 \\
\hline Total & 200 & 200 & 400 & 59 & 49 & 108 \\
\hline
\end{tabular}

Source: Field work, July 2018

The qualitative data was in the form of texts and narratives by the respondents (Creswell, 2014). It constituted a major component in the study. The purpose of this was to understand the realities from the perspectives of the slum dwellers. In each cluster, we had Focus Group Discussions (FGDs) on the importance of social networks in the slums and opportunities in the slums with Youth (males and females) and Adults (males and females) who were not part of those interviewed. In all, we had eight FGD sessions with the number of participants ranging from 10 to 17 as shown in Table 1. In-depth face-to-face interviews were conducted with at least one high profile officer in institutions responsible for making cities resilient in Ghana such as the MLGRD, MWR, MWH, MICZD, EPA, Ghana Police Service, Ghana National Fire Service and AMA. In addition, snowball technique was used to identify three Assembly members and Unit Committee members for interview as key informants from each community.

The Statistical Product and Service Solutions (SPSS) version 20 computer-based software was used to analyse the quantitative data by generating frequencies and cross tabulation of age, sex and migration history (Table 2). For the qualitative data, the text and narratives were coded around the questions and their contents analyzed.

\section{Findings and Discussion}

Following the presentation of the demographic characteristics of the slum dwellers interviewed, the findings to be discussed show that cultural factors account for in-filling in slums, slum dwellers have no plans to return permanently and there are some opportunities in the slums. The findings also show that weak enforcement of development control regulations and non-involvement of slum dwellers in the decision-making process are the challenges that confront city authorities and slum dweller respectively.

\subsection{Demographic Characteristics of Slum Dwellers Interviewed}

In both communities, seventy-five percent $(75 \%)$ of the male youth were born in the communities while the remaining migrated from other parts of Ghana (see Table 2). About 85 percent of the female youth were born in the study communities and the rest also migrated into these areas. Eighty percent $(80 \%)$ of the adult males migrated from other parts of Ghana, 15 percent were born there while 5 percent had come from neighboring countries. The majority ( $85 \%$ ) of the adult females migrated from other regions of Ghana into the communities. Five percent were born in the study communities and the remaining 10 percent came from neighboring countries. 
Table 2. Place of birth of slum dwellers (Percent)

\begin{tabular}{lcccc}
\hline Place of Birth & $\begin{array}{c}\text { Male Youth } \\
(\mathrm{n}=100)\end{array}$ & $\begin{array}{c}\text { Female Youth } \\
(\mathrm{n}=100)\end{array}$ & $\begin{array}{c}\text { Adult Male } \\
(\mathrm{n}=100)\end{array}$ & $\begin{array}{c}\text { Adult Female } \\
(\mathrm{n}=100)\end{array}$ \\
\hline Within study community & 75 & 85 & 15 & 5 \\
Other regions of Ghana & 25 & 15 & 80 & 85 \\
Neighboring countries & 0 & 0 & 5 & 10 \\
\hline Total & 100 & 100 & 100 & 100 \\
\hline
\end{tabular}

Sample size (n) $=400$

Source: Fieldwork, June 2018

All of the interviewees had lived in the study communities for more than 10 years long enough to build social ties. The period is also long enough for them to have a sense of belongingness to the slum more than any other place as seen in subsequent discussions.

\subsection{Cultural Factors of Informal Ties Account for the In-Filling in the Slums}

The study found that cultural factors contribute to the creation of slums and they help to explain informalities in approved settlements. According to all the adult male and female interviewees, a very important cultural practice among the slum dwellers, which is also common to many Ghanaians, is to live close to relatives, friends and families. This means that friends and families allow others to do extension to their houses. This leads to in-filling and eventually the whole place becomes congested and facilities such as roads and water services break down and deteriorate. An officer at the Physical Planning Department at the AMA reported that:

The people want to live close to friends and relatives due to the support in various forms from the social networks and ties that exist in living in close proximity. Because of this, you find that friends and neighbors allow others to do extension to their facilities such as kiosks. Some even use wood or sandcrete blocks to do the extension for accommodation purposes (Key informant at Physical Planning Department of AMA, June 2018).

Another interviewee noted that:

The slums have a lot of social capital and networks of support system that many of them tap into for survival. Open spaces and existing structures are given out to friends to put up something for sleeping. This explains why many low-income people in the cities find themselves there (Interviewee, Ministry of Inner Cities and Zongo Development, July 2018).

These claims were all supported by findings from FGDs with adult males, females and the youth. Examples of how informal ties were invoked were given in the FGD by some individuals as follows:

This landlord is a friend's uncle. I needed a place and when my friend introduced me to him, he agreed that I raise this structure and live here. We are eight in number so where would we have stayed if we did not get this? (Slum dweller, Agbogbloshie, June 2018).

This structure belongs to my brother-in-law and the other one towards the road belongs to my sister and her husband. I allowed them to do the extension so we can be close together and support one another (Resident, Avenor, June 2018).

This is our family land so we all have a place to raise something small and live with our families. This keeps the extended family together all the time (Resident, Avenor, June 2018).

Officials interviewed at the MLGRD corroborated all these findings. One of them noted that:

The main reason why the whole place is filled up is that friends and acquaintances use the social ties to find places to erect all these structures you find there. Access roads and frontage of existing shacks are given out to friends (Official at MLGRD, June 2018).

This view supports findings of many scholars around the strength of social capital (see Woolcock \& Narayan, 2000; Widner \& Mundt, 1998). According officials at the EPA, the in-filling in the slums through social ties is not strange as similar thing occurs in some of the well-planned and approved so-called high-class residential neighborhoods in the city of Accra. They explained that extensions such as kiosks for hairdressing and beautician salons, shops and other developments in approved residential areas belong to people who get approval to do so through informal 
ties. One of them explained the situation this way:

Many of the approved and well-planned residential neighborhoods such as East Legon, Sakumono and even Airport Residential Area are losing their aesthetic quality due to all kinds of extensions done to existing residential facilities (Official at EPA, July 2018).

These views of MLGRD and EPA officials on how informal ties can explain congestion in residential areas and in the slums were not different from what all the other high profile respondents from the MWH, MWR, MICZD, Ghana National Fire Service and Ghana Police Service had. As noted by Hoxha et al. (2014: 76), "cultural factors can affect urban planners' intentions to regulate public space in a particular way. The effects of cultural identity or ideology on urban planning are significant, but are often overlooked because they are difficult to quantify." Many studies have identified overcrowding and congestion, especially in the slums as more people and immigrants move from rural or undeveloped areas into cities and towns in search of better life (see Ekott, 2018; Elrayies, 2016; UNHabitat, 2013; 2015) but what is not clear is who allows the overcrowding to occur in the first place. Our findings suggest that cultural issue of informal ties cause people to allow friends to move in and cause the overcrowding. The reality is that these enduring cultural factors are important to many and AMA cannot ignore them in the implementation of slum prevention bye-laws. According to the key informant in the AMA, the AMA has used development permit acquisition and occasional decongestion exercises to control the in-filling but these approaches have not worked well and that the major challenge facing the AMA is its inability to enforce development control and implement the relevant slum prevention policies and bye-laws. This is mainly because it is those developers who obtain permits who allow their neighbors to do the in-filling.

\subsection{Plans of Slum Dwellers to Return Permanently}

The study revealed that most of the slum dwellers (about 90\%) did not have plans to return to their places of origin. This finding does not support many policies to prevent slums especially in Ghana that slum dwellers will return to where they have come from (see Adogla-Bessa, 2019; Aba and Owusu, 2018; Broadbent, 2012).

About $90 \%$ of the youth (both males and females) indicated that they had no plans to return permanently to their places of origin. All the FGD participants noted that they were born in the slums and they had no where to go. What one of the female youth said which was supported by all the males and females was that:

My mother gave birth to me and my three sibblings here. We have grown up here with all our friends. We have never been taken back home to the Northern Region where our mother came from so we don't have any plans to go to our hometown. We don't even know anybody there (Female Youth at Agbogbloshie, June 2018).

For the adults, they explained that although they visit their places of origin on festive occasions, they do not have any plans to return permanently. These views were corroborated by a key informant at the AMA that:

I am not surprised at what they are saying because in 2006, the government implemented an initiative to make migrants in the slums to return to their places of origin. The government gave them transportation and even some support to set up small businesses with the understanding that they would go back. Many of them did not go back and the few who went initially have all retuned to Accra (Key informant at AMA, July 2018).

When the adult males and females were asked why they would not return to their places of origin, their reasons included the lack of job opportunities back home ( $85 \%)$, new families had been established (70\%) and they were born in the slums ( $20 \%$ of females and $15 \%$ of the males). Findings from all the FGDs on migration history show that over the last three decades, the poor performance of agriculture and the limited job opportunities in the rural areas have pushed many rural residents to migrate into Accra. The major recipients of over 90 percent of the migrants are the slums such as Agbogbloshie and Avenor. So long as rural conditions have not improved many rural dwellers will move into the cities and the slums will continue to be their destination at least for some time.

These findings suggest that spontaneous decongestion exercises implemented by city authorities, forced eviction exercises and demolition of shacks in the slums and congested urban space cannot be appropriate policy options towards making cities in Ghana resilient. Evidence shows that these actions have not worked (see Ekott, 2018; Elrayies, 2016; Psirmoi, 2018). Therefore, urban planning should accept the reality that slum dwellers would not return in the immediate future, partly due to perceived and some real opportuntities in the slums and then plan accordingly.

\subsection{Opportunities in the Slums}

About $90 \%$ of the adult males and $80 \%$ of adult females interviewed in the two settlements indicated that migrating 
into the slums has helped to improve their living conditions. One of the adult females in Agbogbloshie noted that:

I can say that we enjoy higher standard of living in Agbogbloshie than what we have in the village. We have access to facilities such as schools and hospitals in other parts of Accra. We have electricity here (Resident, Agbogbloshie, August 2018).

Findings from a similar study by BRAC (2016: 82) show that: "households experienced improvement in households' economic condition after migrating from rural areas ... and they enjoyed better standard of living compared to rural life through getting access to facilities like school, hospital, electricity, gas, employment and higher social status."

Many migrants into cities in Africa do so because of the hope of finding jobs for a brighter future. Over $80 \%$ of the male youth in Agbogbloshie and 85\% of their counterparts in Avenor in the individual interviews indicated that they were hopeful of brighter future in the slums. It appears that we find more of slums of hope in many of the residents as described by Stokes (1962). This hope was also expressed during the FGDs. A female youth intimated that:

I hope to save some money from the sale of cooked rice and stew and use it to pay for training in fashion and design. Many of our colleagues have done this so I know it is possible (Female youth, Avenor, August 2018).

According to all the categories of slum dwellers interviewed, the economic activities in and near the slums look promising and thriving. They indicated that they could find space in the Agbogbloshie Market for petty trading. Similar views were expressed by slum dwellers in Avenor who find lucrative means of livelihoods in the lorry stations at the Kwame Nkrumah Circle area. The hope of improving their livelihoods sits in Stokes (1962) idea of slums of hope.

The trading activities included the sale of sachet water, cooked food, vegetables, used clothing and recycled electronic materials. One of the interviewees reported that:

Unless you are lazy otherwise you should be able to at least get your daily bread from this place. (Interviewee, Avenor, August 2018).

Another finding of the study was that, it was easier for the females to find something to do for a living than their male counterparts. For example, the females could easily work as head porters. A key informant at the MICZD corroborated this finding by noting that:

A very important and somehow viable economic activity in the slums and Avenor especially is the sale of cooked food which is why the women easily find jobs. The market activities and the many passengers at the lorry stations imply that they will need food whilst on the go (Key informant, MICZD, July 2018).

Further investigations revealed that slums played positive roles in the urban economy, thereby contributing to national development. A key informant reported that:

"Slums play important role in the economic development of the city. For example, they are the sources of many of the cooked food such as waakye, konkonte, tuwo zafi (tz), and awusa kooko (porridge). These are local foods that are claimed by many as healthy and nutritious (Key informant, Ministry of Inner Cities and Zongo Development, August 2018).

Other respondents had the view that many of the slum dwellers played a role of scavenging and recycling, thereby contributing to waste management. The average generation rate of wastes in Africa is about $0.78 \mathrm{~kg} / \mathrm{person} / \mathrm{day}$ while that of Accra is about $0.40 \mathrm{~kg} /$ person/day (Boadi \& Kuitunen, 2003; Agyepong, 2018). In total, Accra generates between 1500-1800 tons of waste per day but the AMA has the capacity to collect only $1200(66 \%)$ tons per day (Thompson, 2009). The composition of solid wastes in the study slums included paper; glass; plastic, electronic waste, automobile waste, and building material waste and scrap iron and tin. This was similar to that in many other slums as noted by Ahsan et al. (1991) cited in Nazrul and Salma (2004) and Thompson (2009). The recycling of the waste by slum dwellers helped to reduce the volume of waste to be cleared by the AMA. This finding supports that of Nazrul and Salma (2004) that slum dwellers in Dhaka City act as receivers of waste disposal service involved in the collection, transportation, disposal, recycling, reusing and composting activities in solid waste management with about 100,000 people directly associated with the process, most of them as informal operators. The recycling activities can provide jobs for slum dwellers if they are organized, trained and regulated.

The finding however, does not support the claims by Thompson (2009) that Accra lacks a substantial sector of 
waste pickers to collect and sort household waste on behalf of merchants, recycling firms, and composting units. There were a number of informal sector waste pickers but they were not documented. One challenge that inhibited the drive to resilient Accra was lack of plan of slum dwellers to return home with the hope that the slums would help them improve their living conditions.

\subsection{Challenges Facing Slum Dwellers and City Authorities}

The study found that the main challenge facing the AMA is weak enforcement of development permit and byelaws and policies on urban development generally and those governing the protection of public open spaces. Existing policies that the AMA can leverage on include the National Environment Policy; the National Climate Change Policy focusing on making Ghanaian cities resilient; Ghana National Urban Policy; and the Ghana National Spatial Development Framework.

For the slum dwellers, their challenge is that city authorities did not involve them in decisions around the management and use of public open space.

\section{Conclusions and Recommendations}

The paper set out to analyze the informal ties that cause in-filling of slums; investigate whether or not slum dwellers have plans to return to their places of origin; examine the opportunities in the slum communities; examine the challenges facing slum dwellers and city authorities; and suggest ways to make the city of Accra resilient. The finding show that slum dwellers are unlikely to return to their places of origin. Their social capital and networks of support systems contribute to why the slums are attractive and explain how the in-filling occurs. Slum dwellers are excluded in urban governance decision process by the AMA and the AMA is faced with the challenge of enforcing urban development policies. In order to make the city of Accra resilient, the following recommendations are made:

\subsection{Strict Implementation of Existing Laws and Policies on Urban Development}

The AMA should strictly enforce the implementation of existing laws and policies on urban development and those governing protected open spaces. These policies include the National Environment Policy; the National Climate Change Policy which focuses on making Ghanaian cities resilient; Ghana National Urban Policy; and the Ghana National Spatial Development Framework.

\subsection{Slum Dwellers Should Be Involved in Urban Development Decisions That Affect Them}

In the implementation of existing laws and policies on urban development and those governing protected open spaces, city authorities and urban planners should involve slum residents in the process. The leadership of slum dwellers should be made to understand that efforts to upgrade the slums are not geared towards driving them out so that they can get their people to cooperate with city authorities. The leadership should utilize their social capital to mobilize their people to support the AMA to upgrade the slums and implement development control to prevent the emergence of new slums.

\subsection{Recognition and Incorporation of Socio-Cultural Issues into Urban Renewal Plans}

There is the need for city authorities to understand and incorporate socio-cultural issues into urban renewal plans to facilitate plan implementation. One of the ways to get slum residents to cooperate with city authorities will be that urban renewal programs should not seek to eliminate the socio-cultural infrastructure of the people or conflict with them such that the resources of survival inherent in the networks and ties are undermined.

\subsection{Implementation of Policies by Ghana Government to Minimize Rural-Urban Migration}

The government of Ghana should implement policies targeted at rural development to make rural areas attractive. The Rural Development Policy should be implemented with adequate commitment. This must seek to adequately support farming to make agriculture attractive. In addition, the National Youth Policy should be fully implemented especially targeting the capacity building of rural youth in rural enterprises development. The objective should be to help minimize the migration of rural youth into the cities. The implementation of the National Housing Policy to make housing affordable needs to be given adequate commitment to help reduce the development of slums. Making cities resilient will require that the mainstreaming of the issue of slums in all urban development agendas needs to be given the needed political and policy attention by governments and all stakeholders.

\section{References}

Aba, C. O., \& Owusu, G. (2018). Accra's Decongestion Policy: Another Face of Urban Clearance or Bulldozing
$\begin{aligned} & \text { Approach? } \\ & \text { https://www.researchgate.net/publication/328677898_Accra's_Decongestion_Policy_Another_Face_of_Urb }\end{aligned}$ 
an_Clearance_or_Bulldozing_Approach

Accra Metropolitan Assembly (AMA). (2018). Medium Term Development Plan (Unpublished), Accra, AMA.

Accra Metropolitan Assembly (AMA). (2019). Okaikoi South Sub Metropolitan District Council. Retrieved

November 28, 2018, from https://ama.gov.ghsub-metro-detail-php

Adamtey, R., Adjei-Kumi, G., \& Oduro, C. (2018). A Research into Slums and informal Settlements development towards making Ghana's cities resilient. Accra, Good Governance Africa.

Adogla-Bessa, D. (2019). Accra flooding: AMA to clear squatters ahead of desilting of storm drains. Retrieved May 20, 2019, from https://citinewsroom.com/2019/04/accra-flooding-ama-to-clear-squatters-ahead-ofdesilting-of-storm-drains/

Afenah, A. (2010). (Re)claiming Citizenship Rghts in Accra, Ghana. Retrieved May 14, 2019, from http://base.dp-h.info/es/fiches/dph/fiche-dph-8430.html

Agyeman-Duah, B. (2005). Deepening Decentralization in Ghana: Towards Accountable local governance. In Centre for Democratic Development (Ed.), Roundtable discussion. Accra, Centre for Democratic Development.

Agyepong, K. A. (2018). Waste Mangement Opitions in Ghana, Future Strategy. Retrieved March 13, 2019, from https:/imaniafrica.org/2018/04/12/waste-management-options-ghana-future-strategy/

Akuffo, S. (2014). IGC Africa growth forum 2014, building effective cities for Growth. Retrieved from https:/www.theigc.org/wp-content/uploads/2014/08/Steve-Akuffo-Presentation-0.pdf

Albino, V., Umberto, B., \& Dangelico, R. M. (2015). Smart Cities : Definitions, Dimensions, Performance, and Initiatives. Journal of Urban Technology, 37-41. https://doi.org/10.1080/10630732.2014.942092

Alesina, A., \& Giuliano, P. (2007). The Power of the Family (The Institute for Labour Studies - IZA Discussion Paper No. 2750). Bonn, Institute for Labour Studies - IZA.

Amoako, C., \& Cobbinah, P. B. (2011). Slum improvement in Kumasi Metropolis, Ghana; a review of approaches and results. Journal of Sustainable Development in Africa, 13(8), 150-170.

African Development Fund. (2015). Ghana: Urban Poverty Reduction Project. Retrieved October 20, 2020 from https:/www.afdb.org/en/news-and-events/ghana-urban-poverty-reduction-project-3595

Ayee, A. J. R. (2008). Decentralisation and Governance in Ghana. Regional Development Dialogue, 29 , 34-52.

Blair, H. (2000). Participation and Accountability at the Periphery: Democratic Local Governance in Six Countries. World Development, 28, 21-39. https://doi.org/10.1016/S0305-750X(99)00109-6

Boadi, K. O., \& Kuitunen, M. (2003). Municipal Waste Management in the Accra Metropolitan Area, Ghana. The Environmentalist, 23, 211-218. https://doi.org/10.1023/B:ENVR.0000017283.09117.20

BRAC. (2016). Livelihood of Slum-Dwellers: Findings from Baseline Survey of Ultra Poor Programme. BRAC Research and Evaluation Division.

Broadbent, E. (2012). Research-based evidence in African policy debates: Case study 1 Decongestion in Accra, Ghana. Retrieved April 25, 2019, from https://www.odi.org/sites/odi.org.uk/files/odi-assets/publicationsopinion-files/9119.pdf

Cassels, S., \& Jenness, S. (2014). Migration, sexual networks and HIV in Agbogbloshie, Ghana. Retrieved May 14, 2019, from https://www.ncbi.nm.nih.gov/pmc/articles/PMC4214381/

Centre for Democratic Development (CDD). (2005). Decentralization and Local Government in Ghana (Papers from a roundtable discussion). In Centre for Democratic Development (Ed.), Roundtable discussion. Accra, Centre for Democratic Development.

Cheema, S. S., \& Rondinelli, D. (2007). From Government Decentralization to Decentralized Governance. In Cheema, G. S., \& Rondinelli, D. (Eds.), Decentralizing Governance: Emerging Concepts and Practices. (pp. 1-20). Washington, D. C. Brookings Institution Press.

CHF International. (2009). Annual Report: Integrated Approach to Development. Silver Spring, Washington, D.C.

Cities Alliance. (2014). About Slum Upgrading. Retrieved March 23, 2018, from http://www.citiesalliance.org/About-slumupgrading\#Why_is_slum_upgrading_important

Cities Alliance. (2019). About Slum upgrading. Retrieved May 14, 2019, from 
https://www.citiesalliance.org/about-slum-upgrading\#What_are_slums

Clark, G. (1999). Negotiating Asante Family Survival in Kumasi, Ghana. Journal of the International African Institute, 69, 66-86. https://doi.org/10.2307/1161077

Coleman, J. S. (1991). Prologue: Constructed Social Organization. In Bourdieu, P., \& Coleman, J. S. (Eds.), Social Theory for a Changing Society. Boulder, Westview Press.

Cohen, B. M. (2006). Urbanization in Developing Countries: Current Trends, Future Projections, and Key Challenges for Sustainability. Technology in Society, 28(1-2), 63-80. https://doi.org/10.1016/j.techsoc.2005.10.005

Crawford, G. (2010). Decentralization and struggles for basic rights in Ghana: opportunities and constraints. The International Journal of Human Rights, 14, 92-125. https://doi.org/10.1080/13642980902933720

Creswell, J. W. (2014). Research Design: Qualitative, Quantitative and Mixed Approaches (4th ed.). Thousand Oaks, California: London, Sage Publications.

Crook, R. C. (2003). Decentralization and Poverty reduction in Africa: The Politics of local - central relations. Public Administration and Development, 23, 77-88. https://doi.org/10.1002/pad.261

Devas, N. (2008). Decentralization and the Implications for Local Government Finance. In Nick Devas, Alam, M., Delay, S., Koranteng, R. O., \& Venkaachalam, P. (Eds.), Financing Local Government (Commonwealth Secretariat Local Government Reform Services. London, Commonwealth Secretariat. https://doi.org/10.14217/9781848590076-en

DFID. (2008). DFID's Contribution to Decentralization and Local Governance (D/LG): A Stocktake. London, DFID.

Ekott, I. (2018). Living on the frontline. Africa in Fact, the Journal of Good Governance Africa, 45, 94-99.

Elrayies, G. M. (2016). Rethinking Slums: An Approach for Slums Development Towards Sustainability. Journal of Sustainable Development, 9(6), 225-244. https://doi.org/10.5539/jsd.v9n6p225

Environmental Justice Organization. (2017). Agbogbloshie E-Waste Landfill, Ghana. Retrieved May 14, 2019, from https://ejatlas.org/conflict/agbogbloshie-e-waste-landfill-ghana

Ghana Satistical Service. (2012). 2010 Population and Housing Census; Summary Report of Final Result. Accra, Ghana Statistical Service.

Ghanaweb. (2020). Old Fadama demolition: Evacuate affected persons to Trade Fair - Amnesty International. Retrieved April 17, 2020, from https://www.ghanaweb.com/GhanaHomePage/NewsArchive/Old-Fadamademolition-Evacuate-affected-persons-to-Trade-Fair-Amnesty-International-926830

Gilbert, A. (2007). The Return of the Slum: Does Language Matter? International Journal of Urban and Regional Research, 31(4), 697-713. https://doi.org/10.1111/j.1468-2427.2007.00754.x

Gill-Chin, L. (1987). Housing Policies for the Urban Poor in Developing Countries. Journal of the American Planning Association, 53(2), 176-185. https://doi.org/10.1080/01944368708976650

Gowda, K., Chandrashekar, M. N., Sridhara, M. V., \& Hemalatha, B. N. (2013). Solid Waste Management in the Slums and Squatter Settlements in the City of Bangalore. International Journal of Scientific and Research Publications, 3(2), 1-10. Retrieved May 14, 2019, from http://www.ijsrp.org/research-paper-0213/ijsrpp14151.pdf

Granovetter, M. (1983). The Strength of Weak Ties: A Network Theory Revisited. Sociological Theory, 1, 201233. https://doi.org/10.2307/202051

Grodeland, A. B. (2005). Informal Networks and Corruption in the Judiciary: Elite Interview Findings from the Czech Republic, Slovenia, Bulgaria, and Romania. New Frontiers of Social Policy. Arusha Tanzania.

Hanson, K. T. (2004). Landscape of survival and escape: social networking and urban livelihoods in Ghana. Environment and Planning, 37, 1291-1310. https://doi.org/10.1068/a3750

Hoxha, V., Andrews K. D., \& Alenka T. S. (2014). Cultural factors affecting urban planners' Intentions to regulate public space in Prishtina, Kosovo. Sistemi urbani., 25, 76-89. Retrieved April 12, 2019, from https://www.researchgate.net/publication/273449061_Cultural_factors_affecting_urban_planners'_intention s_to_regulate_public_space_in_Prishtina_Kosovo

ICLEI. (2017). Resilient Cities Report 2017 Tracking local progress on the resilience targets of SDG 11, 1-28. 
Retrieved

from https://resilientcities2018.iclei.org/wpcontent/uploads/2017/11/RC2017_Report_Online_26102017_Finalcompressed.pdf

Jabareen, Y. (2013). Planning the resilient city: Concepts and strategies for coping with climate change and environmental risk. Cities, 31, 220-229. https://doi.org/10.1016/j.cities.2012.05.004

Johnson, J. B., \& Reynolds, H. T. (2005). Political Science Research Methods (5th ed.). Washington, DC: CQ Press.

Kimenyi, M., \& Mbaku, M. J. (2004). Ethnicity, Institutions and Governance in Africa. In M. Kimenyi, \& P. Meagher (Eds.), Devolution and Development: Governance Prospects in Decentralizing States, (pp. 105-136). England, ASHGATE Publishing Limited.

Komninors, N., March, P., \& Schaffers, H. (2013). Special Issue on Smart Cities and the Future Internet in Europe. J Knowl Econ, 4, 119-134. https://doi.org/10.1007/s13132-012-0083-x

Myjoyonlie. (2019). Sunday downpour: NADMO confirms multiple deaths in Accra. Retrieved April 26, 2019, from https://www.myjoyonline.com/news/2019/April-8th/sunday-downpour-nadmo-confirms-multipledeaths-in-accra.php

Nazrul I., \& Salma, S. A. (2004). Solid Waste Management and the Urban Poor in Dhaka. Paper presented at the Forum on Urban Infrastructure and Public Service Delivery for the Urban Poor Regional Focus: Asia New Delhi, India, 24-25 June 2004. Retrieved May 14, 2019, from https://www.wilsoncenter.org/sites/default/files/Islam\%20and\%20Shafi.doc

Neirotti, P., De Marco, A., Cagliano, C. A., Mangano, G. \& Scorrano, F. (2014). Current trends in Smart City initiatives: Some stylised facts. Cities, 38, 25-36. https://doi.org/10.1016/j.cities.2013.12.010

Obeng-Odoom, X., \& Amedzro, F. (2011). Inadequate housing in Ghana. Urbani Jzziv, 22(1). https://doi.org/10.5379/urbani-izziv-en-2011-22-01-004

Oteng-Ababio, M. (2019). Six Myths About Electronic Waste in Agbogbloshie, Ghana. Retrieved May 14, 2019, from https://africasacountry.com/2019/03/six-myths-about-electronic-waste-in-agbogbloshie-ghana

Oyugi, W. O. (2000). Editorial Introduction: Decentralization for Good Governance, the Unending Debate. Regional Development Dialogue, 21, i-xix.

Oyugi, W. O. (2008a). Editorial Introduction. Regional Development Dialogue, 29(2), iii-ix.

Oyugi, W. O. (2008b). The Performance of Decentralization Efforts in Africa. Regional Development Dialogue, 29(2), 1-14.

Parmer, S., Kavishvar, A., Patni, M. A., \& Shah, H. (2016). A study to understand the Livelihood issues affecting people resettled from slums to economically weaker section. Retrieved November 24, 2019, from https://www.ejmanager.com/mnstemps/67/67-1445177035.pdf?t=1574599299

Psirmoi, D. (2018). Land grabs and muggers. Africa in Fact, the Journal of Good Governance Africa, 45, 100-104.

Republic of Ghana. (1992). 1992 Constitution of the Republic of Ghana. Accra, Government Printer.

Republic of Ghana. (1993). Local Government Act, 1993 (Act 462). Accra, Ghana Publishing Company Limited.

Republic of Ghana. (2016a). Land Use and Spatial Planning Act, 2016 (Act 925). Accra, Ghana Publishing Company Limited.

Republic of Ghana. (2016b). Local Governance Act, 2016 (Act 936). Accra, Ghana Publishing Company Limited.

Republic of Ghana. (2017). Zongo Development Fund Act, 2017 (Act 964). Accra, MLGRD.

Rondinelli, D. A. (1990a). Decentralizing Urban Development Programs: A Framework for Analysing Policy Options. Washington, DC: USAID Office of Housing.

Rondinelli, D. A. (1990b). Decentralization, Territorial Power and the State: A Critical Response. Development and Change, 21, 491-500.

Smith, B. C. (1985). Decentralization: The Territorial Dimension of the State. London, George Allen and Unwin.

Stokes, J. C. (1962). A Theory of Slums. Land Economics, 3(38), 187-197. https://doi.org/10.2307/3144581

Thompson, I. A. (2009). Domestic Waste Management Strategies in Accra, Ghana and Other Urban Cities in Tropical Developing Nations. Retrieved April 10, 2019, from 
https://case.edu/med/epidbio/mphp439/Waste_Mgmt_Accra.pdf

UN-Habitat. (2010). State of the World's Cities 2010/2011. Nairobi, United Nations Human Settlements Program.

UN-Habitat. (2011). Ghana Housing Profile: UN-HABITAT. (Volume): 978-92-1-132416-7. Nairobi, United Nations Human Settlements Programme (UN-HABITAT). Retrieved April 14, 2018, from http://www.unhabitat.org

UN-Habitat. (2013). Global Urban Indicators Database. Retrieved from http://www.unhabitat.org/stats/Default .aspx

UN-Habitat. (2015). Approaches to slum upgrading and informal settlement regularization. Retrieved from https://unece.org/fileadmin/DAM/hlm/wpla/workshops/informal_settlements_2015/presentations/2.2_Lenz. pdf

UN-Habitat. (2020). Ghana slums lined up for investment. Retrieved November 16, 2020, from https: $/ /$ mirror.unhabitat.org $/$ content.asp? cid $=2438 \&$ catid $=542$ \&typeid $=6$

United Nations Human Settlements Program (UNHSP). (2003). The Challenge of Slum: Global Report on Human Settlements. London, Earthscan Publications Limited.

United Nations. (2016). UN Sustainable Development Goals. Retrieved May 19, 2019, from https://www.undp.org/content/dam/undp/library/corporate/brochure/SDGs_Booklet_Web_En.pdf

Wagner, I., \& Breil, P. (2013). The role of ecohydrology in creating more resilient cities. Ecohydrology \& Hydrobiology, 13(2), 113-134. https://doi.org/10.1016/j.ecohyd.2013.06.002

Wanyande, P. (2004). Decentralization and Local Governance: A Conceptual and Theoretical Discourse. Regional Development Dialogue, 25, 1-13.

Weinstein, L. (2014). The Durable Slum - Dharavi and the Right to Stay Put in Globalizing Mumbai. Hyderabad, Orient Blackswan.

Wekwete, K. H. (2007). Decentralization to Promote Effective and Efficient Pro-Poor Infrastructure and Service Delivery in the Least Developed Countries. In S. G. Cheema, \& D. Rondinelli (Eds.), Decentralizing Governance; Emerging Concepts and Practices (pp. 242-265). Washington, DC: Brookings Institution Press.

Widner, J., \& Mundt, A. (1998). Researching Social Capital in Africa. Africa: Journal of the International African Institute, 68, 1-24. https://doi.org/10.2307/1161145

Woolcock, M., \& Narayan, N. (2000). Social Capital: Implications for Development Theory, Research, and Policy. World Bank Research Observer, 15, 225-249. https://doi.org/10.1093/wbro/15.2.225

World Bank. (2004). Making Services Work for Poor People (World Development Report 2004). Washington, DC: World Bank.

\section{Copyrights}

Copyright for this article is retained by the author(s), with first publication rights granted to the journal.

This is an open-access article distributed under the terms and conditions of the Creative Commons Attribution license (http://creativecommons.org/licenses/by/4.0/). 